九州大学学術情報リポジトリ

Kyushu University Institutional Repository

\title{
Performance Evaluation of Updraft Air Tower Power Plant Integrated with Double Skin Solar Air Heater
}

\section{Ali A. Ismaeel}

Electromechanical Engineering Department, University of Technology

Hasanain A. Abdul Wahhab

Mechanical Engineering Department, University of Technology

Zainab H. Naji

Mechanical Engineering Department, University of Technology

https://doi.org/10.5109/4480706

出版情報 : Evergreen. 8 (2)，pp.296-303，2021-06. Transdisciplinary Research and Education Center for Green Technologies, Kyushu University

バージョン :

権利関係 : 


\title{
Performance Evaluation of Updraft Air Tower Power Plant Integrated with Double Skin Solar Air Heater
}

\author{
Ali A. Ismaeel ${ }^{1}$, Hasanain A. Abdul Wahhab ${ }^{2, *}$, Zainab H. Naji ${ }^{2}$ \\ ${ }^{1}$ Electromechanical Engineering Department, University of Technology, Baghdad, Iraq \\ ${ }^{2}$ Mechanical Engineering Department, University of Technology, Baghdad, Iraq
}

*Author to whom correspondence should be addressed:

E-mail: 20085@uotechnology.edu.iq

(Received November 24, 2020; Revised March 21, 2021; accepted May 9, 2021).

\begin{abstract}
This paper presents and discusses a novel Computational Fluid Dynamics simulation of a solar air heater as part of the updraft air tower model for an electrical power generation. A solar air heater is built upon double transparent upper skin to capture the solar energy and create the greenhouse effect, which is forming hot air flow into power generator part. The influence of different transparent skin geometrical of the proposed solar air heater on the tower power plant performance at various operational parameters have been simulated and evaluated using ANSYS Fluent software to solved the Navier-Stockes and energy equations integrated with discrete ordinates (DO) radiation model. The evaluation result demonstrates that as the number of skin solar air heater in collector increases, also the area of these air heaters, the system performance enhances.
\end{abstract}

Keywords: energy recovery; solar air heater; solar chimney power plant; solar air collector

\section{Introduction}

In today's scenario requirement of clean energy is increasing at industrial as well as domestic level. So nowadays, solar heaters collector is being used to utilize renewable sources of energy ${ }^{1,2)}$. Many researchers interested to study the thermal performance of different solar systems; solar distiller to enhance the heat input and yield rate ${ }^{3)}$, solar water heaters ${ }^{2,4)}$.

Solar updraft tower power plant SUTPP is a plant to generate electricity from solar irradiation depending on buoyancy force to drive air to ascend ${ }^{5)}$. The SUTPP parts are simple and free of complexity in the design, operation, and maintenance. Main parts of the SUTPP are a solar air collector (SAC), tower and turbine, as shown in Fig.1. Conventionally, the solar beams are penetrated through the transparent cover of collector and received by the absorber medium (ground) and the air inside of solar collector. But the ground has some drawbacks, such as limited storage capacity, thermal leakage and enhances thermal storage requirements. However, the energy storage can be used to improve these systems during night or cloudy days; the stored heat in the absorber medium is released to the collector air. The temperature or the difference in density between the ambient and the inner collector warm air generates buoyancy force which considered driving force or pressure potential. Warm airflow towards the tower base and drive the power conversion unit (turbine) and powering generator ${ }^{6}$. Therefore, enhanced the SAC part was focused by the previous studies to maintain a high-performance level of SUTPP. Three class have been examined by previous studies can be classification, the first class analysis the effect of absorber mediums deposition characterized on the SAC outcomes. In this regard, wide ranges of attempts have been reported, Al-Kayiem et al. ${ }^{7)}$ summarized the advantage and disadvantage of each thermal storage technique in the SCPP which suggested by many previous researchers. Wahhab and Al-Maliki ${ }^{8)}$ studied the enhancement of the efficiency of energy conversion of the collector and extending the operation time using a six type of natural ground materials, the study recommended using the black stones as a thermal heat storage media of the collector for its efficiency, low cost, and availability. Fadaei et al. ${ }^{9)}$ evaluated the effect of utilizing paraffin wax as a phase change material for heat storage in the constructed SAC. The results in this study showed increasing the average mass flow rate of SUTPP model around $8.33 \%$. Liquid heat storage system was proposed by Kreetz ${ }^{10)}$ and Schlaich et al. ${ }^{11}$ by adding closed water-filled systems with different heat storage mechanisms, the researchers showed that the SCPP with closed water-filled systems can generate power at night but with decline in power generation during sunshine. The second class of researchers proposed to join the SAC with external heat source to allow the SUTPP works 24 hours. In line with this, Chikere et al. ${ }^{12)}$ studied how can 
benefit from the thermal energy which came from the flue gases of the thermal power plant to enhance the performance of the SUTPP. Later Al-Kayiem et al. ${ }^{13)}$ design hybrid arrangement model by used Flue-gas channels that employed to supplying hot air into SAC passage. The study showed that the model resolves the drawbacks of night hours and enable the SUTPP operation 24 hours' electricity power production. Where, the third class of researchers investigated the geometrical shape of SAC. For example, Different configurations of the collector i.e. converging flow, diverging flow and parallel flow were studied numerically by Semai et al. ${ }^{14)}$. Double passes counter flow was investigated numerically and compared with the conventional SAC design by Larbi et al. ${ }^{15)}$, the study appeared enhanced the SAC efficiency about 28\%. Therefore, continuously the studies on various design of SAC is consider necessary to investigate the flow visualization within SAC and it is effect on efficiency ${ }^{16-21)}$. Hence, a new model of SAC consisted from double transparent skin surface (DTSS) to upgrade the SAC efficiency has been devised and proposed in this work ${ }^{22-26)}$. In details, different DTSS geometrical at variable operating parameters has been simulated by using ANSYS FLUIENT computational fluid dynamics (CFD) to evaluate the optimum design of the SAC part for the SUTPP future work development.

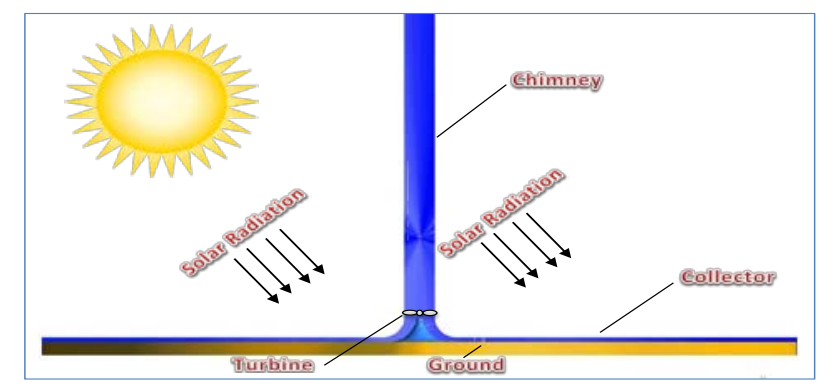

Fig. 1: Schematic diagram of solar power plant updraft tower.

\section{Guidelines of SUTPP Design}

In design of a collector for solar chimney power plant, further considerations in the design of solar chimney plant including diameter and height of the inlet air as well as chimney base height all pertaining collector, ground material, and transforming power system ${ }^{27-31)}$. Generally, single skin solar heaters are the most used to date, especially those operating at low height for the collector, variable speed turbines are often installed in the upper point for solar collector (chimney base), and the air speed is increasing in an effort to improve power capture, reduce loads, obtain better energy quality, and enable more advanced aspects of power control. In this investigation, three simulated models were performed, normal design which is the first model given by 13) (single solar air heater with diameter $6 \mathrm{~m}$ ), (Model A) is the second model having double skin solar air heater with diameter $6 \mathrm{~m}$ as can be seen in Fig.2 (a), and third model (Model-B) is double skin solar air heater with diameter $2.8 \mathrm{~m}$ as shown in Fig.2 (b). The main inputs were:

- The range of solar intensity $\left(50-950 \mathrm{~W} / \mathrm{m}^{2}\right)$ with;

- Ambient air temperature $\left(30-34^{\circ} \mathrm{C}\right)$;

- Ground, it is supposed to be $10 \mathrm{~cm}$ thick.

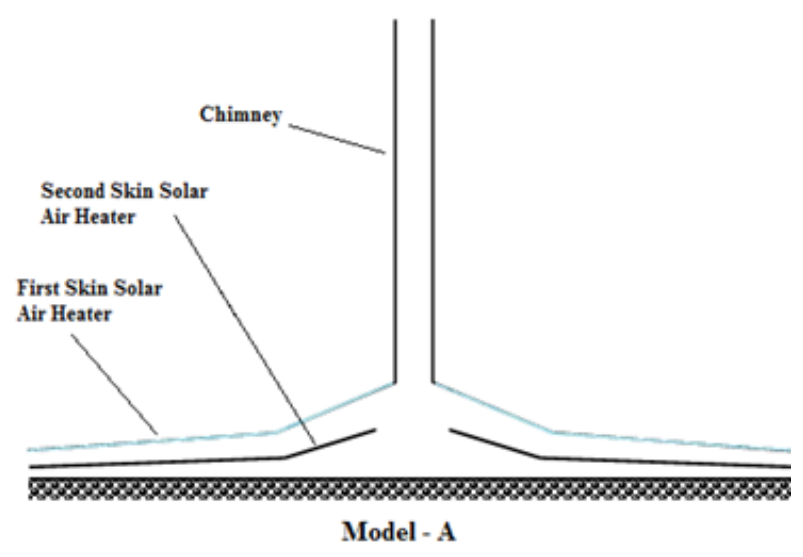

(a)

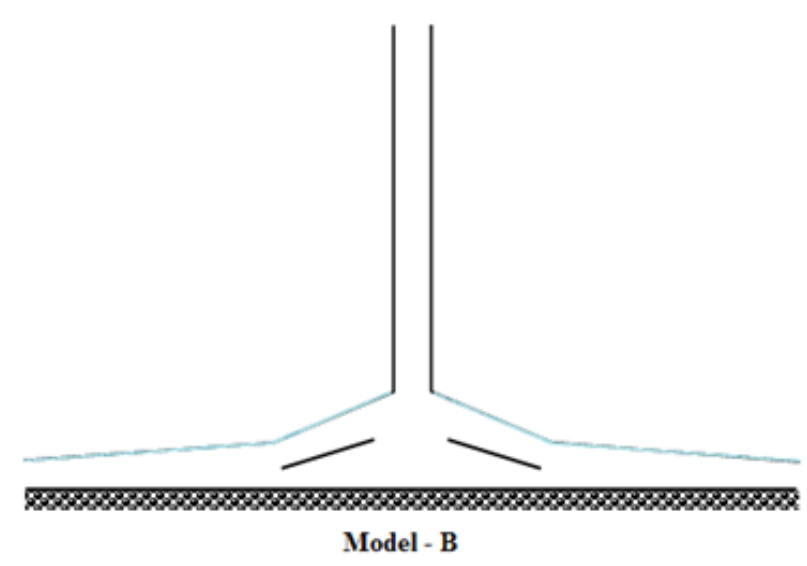

(b)

Fig. 2: Schematic of the double skin solar air heater: (a) Model-A, and (b) Model-B.

\section{Numerical Implementation}

ANSYS Fluent Workbench 15, Inc. specifically finite volume method was employed to build computational domain finite volume models. GAMBIT 2.4.6 preprocessing tool support $3 \mathrm{D}$ modeling air collector geometry of the solar system in accordance to the parameters of the prototype. Physical phenomena were all simulated using Computational Fluid Dynamics (CFD) techniques as well as prediction of air thermal properties and dynamic behavior of air in 3D cylindrical coordinates. The discretization of equations named; continuity, energy and Navier-Stoke's was performed utilizing Finite Volume Method (FVM) 


\subsection{Numerical Method}

To analysis energy system, the 3D numerical simulation was depending on K-epsilon (k- $\varepsilon$ ) model. According to the features of the turbulent dispersion rate and the turbulence kinetic energy, the values of various constants adopted for $\mathrm{k}-\varepsilon$ turbulence model were presented in Table 1. The turbulence kinetic energy is specified from turbulence field, and defined as:

- The solar beam calculation in terms of diffuse and direct intensity are depending on system location. So, at specific location and time in regard to the solar beam, the user can be limiting them, and specifying of the solar values and directions are controlling by solar calculator. However, the intensity calculations are performed by utilizing the Discrete Ordinates (DO) method.

- The potential for grid error is due to extreme fluid domain distortion. Therefore, the dynamic mesh is used to simulate the transient flow behavior of the fluid domain and the aero elastic deformation. The adaptation of remeshing is however appropriate for large displacement and deformation. Therefore, nodes relocating is utilized in accordance to smoothing techniques.

Table 1. Various constants adopted for k- $\varepsilon$ turbulence model.

\begin{tabular}{|c|}
\hline Transport equations for standard $k-\varepsilon$ model \\
\hline $\begin{array}{l}\text { For turbulent kinetic energy } k \\
\qquad \frac{\partial}{\partial t}(\rho k)+\frac{\partial}{\partial x_{i}}\left(\rho k u_{i}\right)=\frac{\partial}{\partial x_{j}}\left[\left(\mu+\frac{\mu_{t}}{\sigma_{k}}\right) \frac{\partial k}{\partial x_{j}}\right]+P_{k}+P_{b}-\rho \epsilon-Y_{M}+S_{k} \\
\text { For dissipation } \epsilon \\
\qquad \frac{\partial}{\partial t}(\rho \epsilon)+\frac{\partial}{\partial x_{i}}\left(\rho \epsilon u_{i}\right)=\frac{\partial}{\partial x_{j}}\left[\left(\mu+\frac{\mu_{t}}{\sigma_{\epsilon}}\right) \frac{\partial \epsilon}{\partial x_{j}}\right]+C_{1 \epsilon} \frac{\epsilon}{k}\left(P_{k}+C_{3 \epsilon} P_{b}\right)-C_{2 \epsilon} \rho \frac{\epsilon^{2}}{k}+S_{\epsilon}\end{array}$ \\
\hline 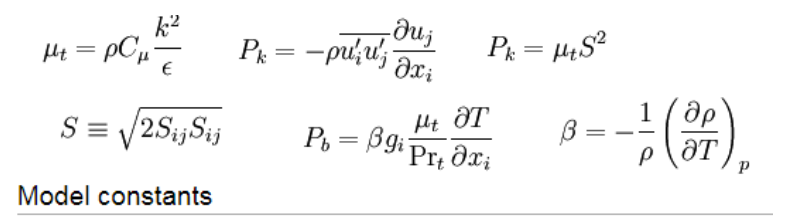 \\
\hline$C_{1 \epsilon}=1.44, \quad C_{2 \epsilon}=1.92, \quad C_{\mu}=0.09, \quad \sigma_{k}=1.0, \quad \sigma_{\epsilon}=1.3$ \\
\hline
\end{tabular}

\subsection{Governing Equations}

batches are considered to represent the flow of air in the chimney of the solar power plant along with the external air. this is because the air inflow in related to the system is contrast with internal collector temperature and some other environmentally influences such as humidity and wind. The determination of buoyant air of the solar power plant from the base of the collector exit(chimney) is illustrated in equation 1 :

$$
\frac{\partial}{\partial r}\left(\rho_{\text {air }} V_{\text {coll }} r_{\text {coll }} H_{g-c}\right)=0
$$

based on equation 1 , density and velocity of air are a function of the internal collector temperature area. While the potential air volume in the system is determined of the collector canopy height that located above the ground. on the same manner, equation 2 described the continuity of air flow in the chimney. Hence, mass continuity and balance are considering.

$$
\frac{\partial}{\partial h}\left(2 \pi \rho_{\text {air }-c h} V_{a i r-c h} r_{c h} H_{c h}\right)=\frac{\partial}{\partial h}\left(\rho_{\text {air }-c h} \dot{V}_{\text {air }-c h}\right)=0
$$

The buoyant air strength that reaching the turbine is described by the momentum of air flow in the collector. this air property is calculated using equation 3 . On the other hand, the momentum of air flow flowing in the chimney is defined in equation 4.

$$
\rho_{\text {air-coll }} V_{\text {coll-exir }} H_{g-c} \frac{\partial V_{\text {coll-exit }}}{\partial r_{\text {coll }}}=-H_{g-c} \frac{\partial p_{\text {air-coll }}}{\partial r_{\text {coll }}}-\tau_{\text {air-coll }}
$$

$$
\rho_{\text {air }-c h} \dot{V}_{\text {air-ch }} \frac{\partial \dot{V}_{a i r-c h}}{\partial h}=-\frac{\partial p_{\text {air-ch }}}{\partial h}-\frac{2 \tau_{\text {air-ch }}}{r_{c h}}-\rho_{\text {air-ch }} g
$$

in this study, the energy equation is the basic equation that considered for the simulation as given in equation 5 .

$$
u \frac{\partial T}{\partial x}+v \frac{\partial T}{\partial y}=\frac{\lambda}{\rho c_{p}}\left(\frac{\partial T^{2}}{\partial x^{2}}+\frac{\partial T^{2}}{\partial y^{2}}\right)
$$

\subsection{Cases of Simulation Parameter and Boundary Conditions}

A radiation model was employed in the simulation in order to assist determining the different temperatures and velocities of the solar system power plant. based on results of simulation, the properties of thermo-physical followed three models along with skin solar air heater. The simulation boundary conditions are illustrated in table 2 .

Table 2. Simulation boundary conditions of the media selection as heat storage.

\begin{tabular}{|l|l|l|}
\hline Component & $\begin{array}{l}\text { Boundary } \\
\text { type }\end{array}$ & Value \\
\hline Ground & Wall & $\begin{array}{l}\text { Adiabatic system (q= 0), } \\
\text { temperature values is a function } \\
\text { of solar intensity, no-slip. }\end{array}$ \\
\hline $\begin{array}{l}\text { Glass of } \\
\text { Model: } \\
\text { normal, A, } \\
\text { and B }\end{array}$ & Wall & $\begin{array}{l}\text { Adiabatic system (q= 0), } \\
\text { temperature values is a function } \\
\text { of solar intensity, no-slip }\end{array}$ \\
\hline $\begin{array}{l}\text { Chimney } \\
\text { walls }\end{array}$ & Wall & $\begin{array}{l}\text { Adiabatic system (q= 0), } \\
\text { temperature values is a function } \\
\text { of solar intensity, no slip }\end{array}$ \\
\hline $\begin{array}{l}\text { Skin solar } \\
\text { heater wall: } \\
\text { normal, A, } \\
\text { and B }\end{array}$ & Wall & $\begin{array}{l}\text { Adiabatic system (q=0), no slip, } \\
\text { temperature values is a function } \\
\text { of solar intensity. Whereas, the } \\
\text { storage materials rely on thermal } \\
\text { properties. }\end{array}$ \\
\hline
\end{tabular}




\begin{tabular}{|l|l|l|}
\hline $\begin{array}{l}\text { Collector } \\
\text { inlet }\end{array}$ & $\begin{array}{l}\text { Mass-flow } \\
\text { inlet }\end{array}$ & $\begin{array}{l}\text { Inlet parameters reliant on } \\
\text { ambient condition. }\end{array}$ \\
\hline Chimney & $\begin{array}{l}\text { Pressure } \\
\text { outlet }\end{array}$ & Pressure difference $(\Delta \mathrm{p}=0)$ \\
\hline
\end{tabular}

In fig. 3 the double skin solar air heater along with the meshing of the 3D model geometry of the chimney pertaining solar power plant is shown. Separate solution of both fluid and solid domain was performed. thereafter, a periodic exchange between the solid and fluid for their interaction information. This concept able for saving time of the computational process and provide adequate precision in solving several complex non-linear problems. It I also used pressure-based type of solver. fine meshing nodes and elements pertaining all models are illustrated in Table 3. For all domains, number of cells in Table 3 selected for all simulation according to grid dependency as shown in Figure 4.

Table 3. Nodes and elements for SUTPP.

\begin{tabular}{|c|c|c|c|}
\hline SUTPP & Dimensions & Nodes & Elements \\
\hline $\begin{array}{l}\text { Model- } \\
\text { normal }\end{array}$ & $\begin{array}{l}\text { Single skin solar air } \\
\text { heater, with diameter } \\
6 \mathrm{~m} \text { and height at } \\
\text { inlet } 0.05 \mathrm{~m} \\
\text { Chimney diameter } \\
0.15 \mathrm{~m} \text {, and height } \\
6.65 \mathrm{~m}\end{array}$ & 818341 & 689433 \\
\hline Model-A & $\begin{array}{l}\text { Double skin air heater } \\
\text { diameter, } 6 \mathrm{~m}\end{array}$ & 807893 & 671994 \\
\hline Model-B & $\begin{array}{l}\text { Double skin air heater } \\
\text { diameter, first skin } \\
\text { diameter } 6 \mathrm{~m} \text {, and } \\
\text { second skin diameter } \\
2.8 \mathrm{~m}\end{array}$ & 813987 & 684663 \\
\hline
\end{tabular}
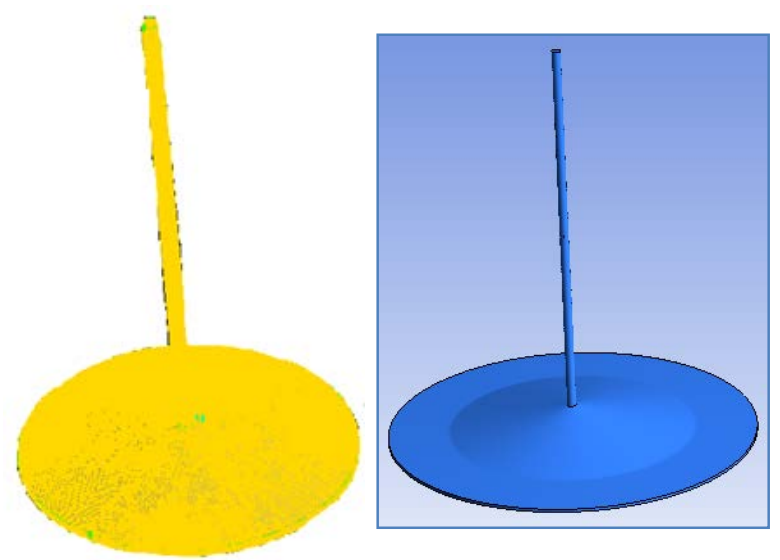

Fig. 3: Mesh and computational domain for the geometrical model of solar chimney power plant.
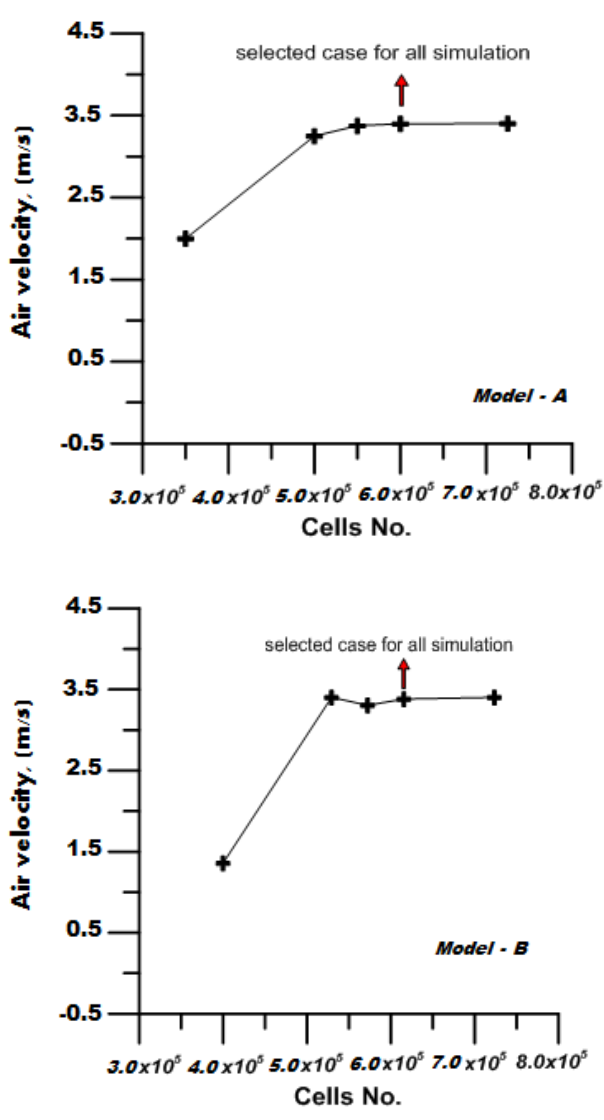

Fig.4: Cells selected for simulation models A and B.

\section{Results and Discussion}

As discussed previously, three different operational models were processed numerical study, whereby Table 3 illustrated analyzed data.

The results of the three different cases of the proposed SUTPP has been explained and identified numerically in this section. normal design pertaining Case 1 is given by 13) (single solar air heater with diameter $6 \mathrm{~m}$ ). Case 2 is double skin solar air heater with diameter $6 \mathrm{~m}$. Case 3is double skin solar air heater with diameter $2.8 \mathrm{~m}$, the operation performed at solar source for all cases in the daytime. The results of velocity were numerically predicted, and the presentation of solar intensity was ranging from 50 to $950 \mathrm{~W} / \mathrm{m}^{2}$ with increment of $100 \mathrm{~W} / \mathrm{m}^{2}$. As can be seen in Fig.5, the maximum velocity values that found for the three cases named: normal, Model-B, and Model-A are 2.82, 3.18, and $3.36 \mathrm{~m} / \mathrm{s}$, respectively, at $950 \mathrm{~W} / \mathrm{m}^{2}$ solar radiation magnitude. These findings occurred at the base of the chimney. 


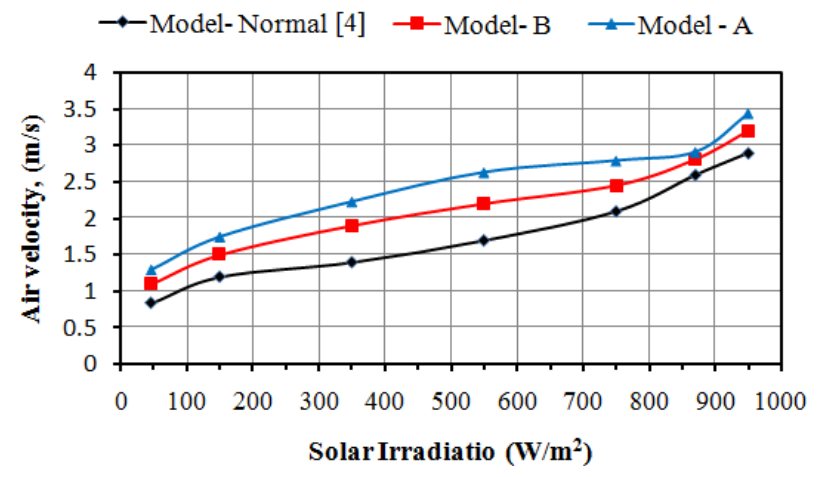

Fig. 5: Velocity of Air at the base of the chimney, for normal model, Model-B and Model-A.

Fig.6 shows the contour maps results of air velocity for different collector design when the solar irradiation at its maximum value. the conditions of the results presented is ranging from single skin solar air heater (normal model) to double skin solar air heater (Model-A and Model-B). The velocity of air at the base of chimney for Model-A has the highest value comparing to other models. This attribute to high internal energy of air in the double-skin solar air heater that having high thermal energy leading to buoyancy forces Stimulation.

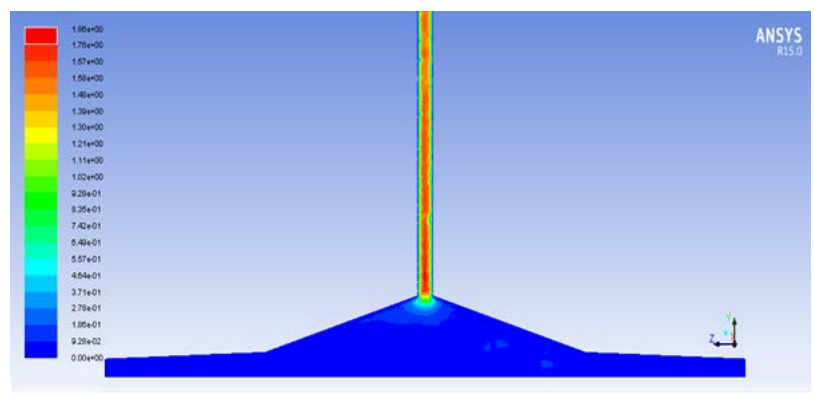

(a)

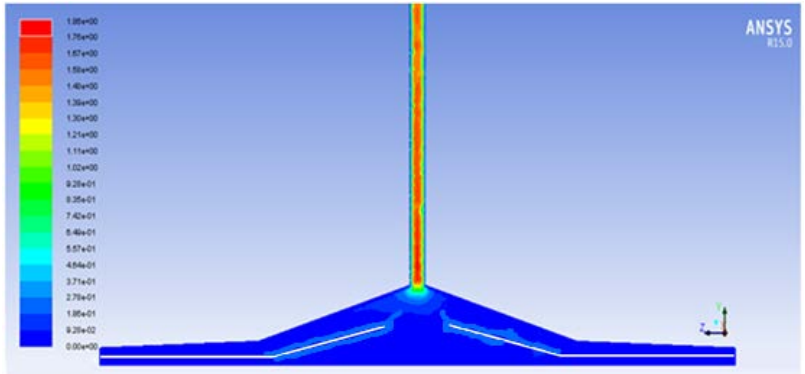

(b)

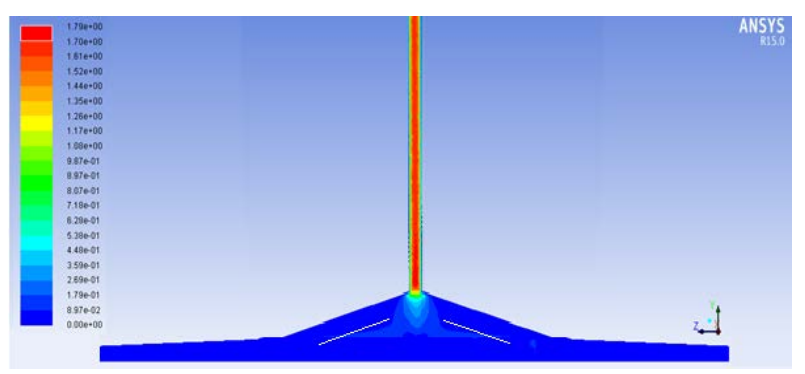

(c)

Fig. 6: Velocity contours at daytime with solar intensity = $950 \mathrm{~W} / \mathrm{m}^{2}$ : (a) normal, (b) Model-A, and (c) Model-B.
The behavior of overall thermal property is explained the efficiency of SUTPP based on the (flow rate of the air mass multiply rising in air temperature [kg/s.K]). Fig. 7 shows that during the daytime hours, the double skin solar air heater having better results of thermal performance when the diameter is $6 \mathrm{~m}$. The improvement in this model is attributed to the increment in the energy that stored at daylight hours as a result of solar radiation explosion. whereby, continues increasing of the solar radiation is occur. Consequently, the collector's efficiency with double-skin air heater is enhanced when compare to the normal model ${ }^{13)}$, and Model-B, especially at the afternoons. The validation of simulation results with the literature review reported in Table 4.

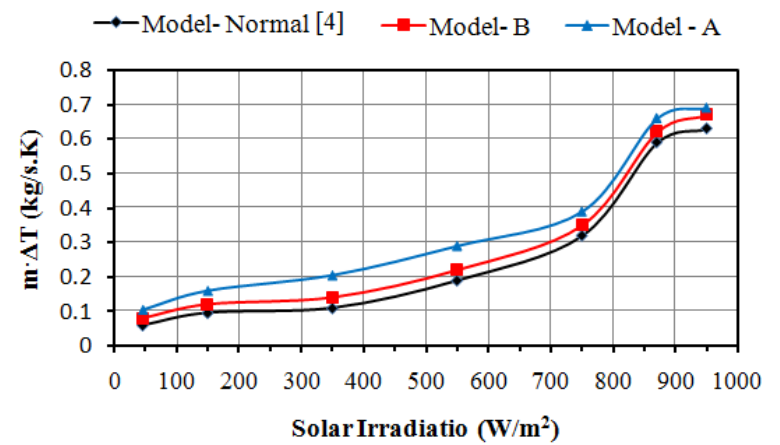

Fig. 7: The performance of SUTPP for the different models.

Table 4. The validation of simulation results for the performance of SUTPP.

\begin{tabular}{|l|l|c|c|}
\hline \multicolumn{2}{|l|}{ Refs } & $\Delta$ T. $\left({ }^{\circ} \mathbf{C}\right)$ & $\begin{array}{l}\text { Percentage } \\
\text { error (\%) }\end{array}$ \\
\hline $\begin{array}{l}\text { Current } \\
\text { work }\end{array}$ & Model-A & 12.3 & $4.6 \%$ \\
\cline { 2 - 4 } & Model-B & 11.4 & $6.3 \%$ \\
\hline $\begin{array}{l}\text { Rifat et al } \\
\text { model) (normal }\end{array}$ & 8.4 & - \\
\hline \multicolumn{2}{|l}{ Wahhab and Al-Maliki ${ }^{8)}$} & 7.4 & $13.4 \%$ \\
\hline
\end{tabular}

Temperature contours is presented in Fig. 8 as resulted from the computational simulation of three models: (a) normal model ${ }^{10)}$, (b) Model-A, and (c) Model-B. At 950 $\mathrm{W} / \mathrm{m}^{2}$, the temperatures results are found to be approximately $51^{\circ} \mathrm{C}, 54^{\circ} \mathrm{C}$, and $52.4^{\circ} \mathrm{C}$ for three models, respectively. At $1 \mathrm{Pm}$ The rising of air temperature, are $17^{\circ} \mathrm{C}, 20^{\circ} \mathrm{C}$, and $18.4^{\circ} \mathrm{C}$. The increasing number of skin solar air heaters or the area of skin solar air heater in SUTPP increases the heating range of the internal air flow of the collector. this increment explained raising the kinetic energy as well as air temperature. pressure contours are shown in Fig. 9 as an outcome of the computational simulation of models: (a) Model-A, and (b) Model-B. 


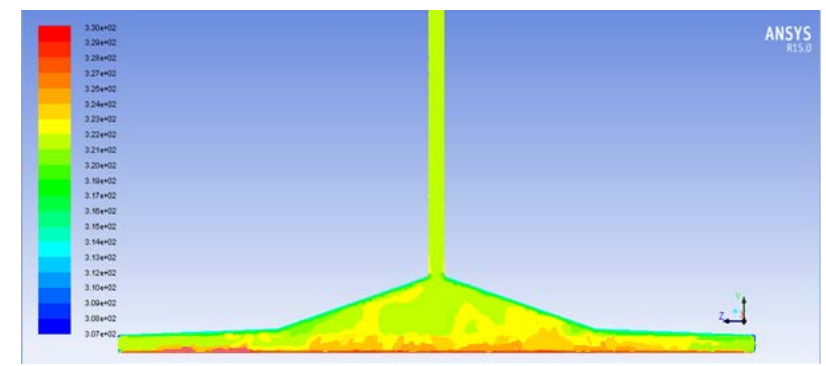

(a)

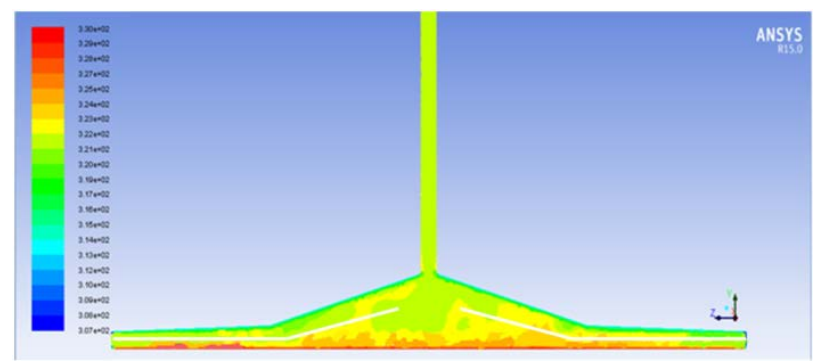

(b)

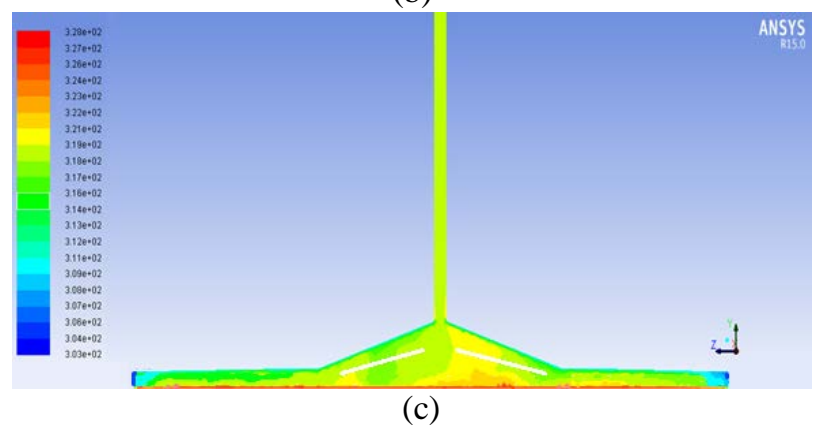

Fig. 8: Temperature contours for the SUTPP at daytime with solar intensity $=950 \mathrm{~W} / \mathrm{m}^{2}$ : (a) normal model, (b) Model-A, and (c) Model-B.

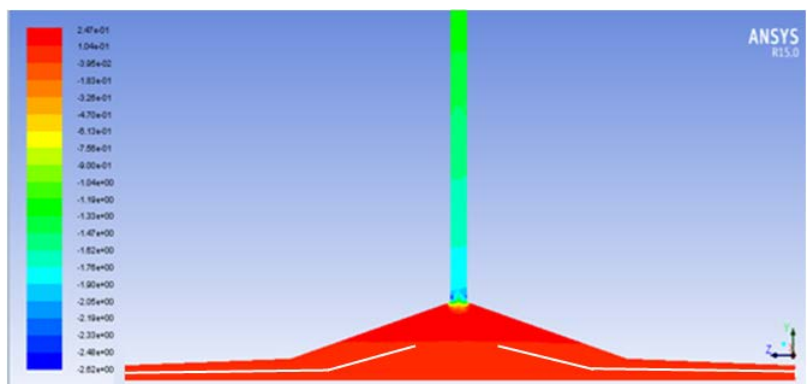

(a)

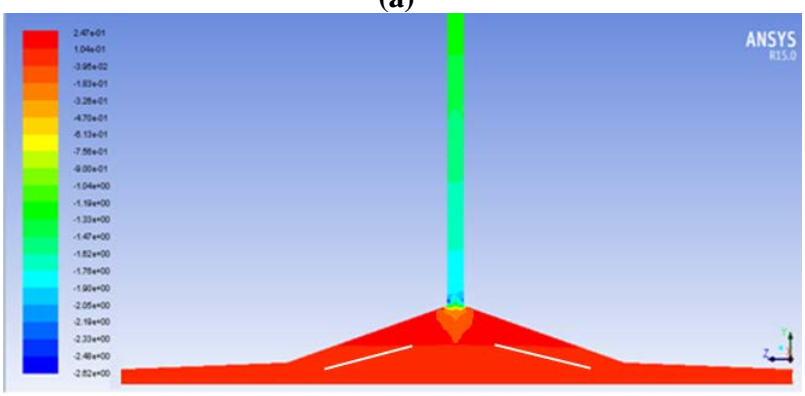

(b)

Fig. 9: Pressure contours for the SUTPP at daytime with solar intensity $=950 \mathrm{~W} / \mathrm{m}^{2}$ : (a) Model-A, and (b) Model-B.

\section{Conclusions}

A numerical modeling for a new structure of double-skin air solar heater is investigated in this study. An analytic solution was performed on three different collector design models. The simulation findings are in a good agreement with the previous published work in the same area. The results revealed that as the number of skin and area of solar air heater in the collector increases, the system performance enhances. The air velocity at the base of the chimney is increased as the number of skin solar air heater in collector increased due to the lower thermal losses to the environment. Also, the results of the simulation show temperatures variation of about $51^{\circ} \mathrm{C}$, $54^{\circ} \mathrm{C}$, and $52.4^{\circ} \mathrm{C}$ for three models, respectively. on the other hand, at $1 \mathrm{Pm}$ the raising of air temperature, were found $17^{\circ} \mathrm{C}, 20^{\circ} \mathrm{C}$, and $18.4^{\circ} \mathrm{C}$.

\section{Acknowledgements}

Authors are obliged to the University of Technology, Baghdad, for providing the centre for renewable and sustainable energy.

\section{References}

1) M.A.dos Santos Bernardes and X. Zhou, "On the heat storage in Solar Updraft Tower collectors-Water bags" Solar energy, 91 22-31 (2013). https://doi.org/10.1016/j.solener.2012.11.025

2) T. Kirti, D. Rahul "Analysis of Modified Solar Water Heating System Made of Transparent Tubes \& Insulated Metal Absorber" Evergreen: Joint Journal of Novel Carbon Resource Sciences \& Green Asia Strategy, 5(1), 62-72 (2018).

3) P. Piyush, K.N. Ajaya, and D. Rahul "A Modified Double Slope Basin Type Solar Distiller: Experimental and Enviro-Economic Study" Evergreen: Joint Journal of Novel Carbon Resource Sciences \& Green Asia Strategy, 5(1), 52-61 (2018).

4) A. R. Rifat, M. A. Hakim Khan, K. M. Ariful Kabir "Energy management and heat storage for solar adsorption cooling" Evergreen: Joint Journal of Novel Carbon Resource Sciences \& Green Asia Strategy, 3(2), 1-10 (2016).

5) R. Vieira, et al. "Numerical evaluation of solar chimney geometry for different ground temperatures by means of constructal design" Renewable Energy, 109 222-234

(2017). https://doi.org/10.1016/j.renene.2017.03.007

6) O.C. A ja, H.H. Al-Kayiem, and Z.A. Karim "Experimental investigation of the effect of wind speed and wind direction on a solar chimney power plant" WIT Transactions on Ecology and the Environment, 179 945-955 (2013).

7) H.H. Al-Kayiem, and O.C. Aja "Historic and recent progress in solar chimney power plant enhancing technologies" Renewable and Sustainable Energy 
Reviews, $58 \quad$ 1269-1292 (2016). https://doi.org/10.1016/j.rser.2015.12.331

8) H.A.A. Wahhab, and W.A.K. Al-Maliki "Application of a Solar Chimney Power Plant to Electrical Generation in Covered Agricultural Fields" in IOP Conference Series: Materials Science and Engineering. IOP Publishing (2020). doi:10.1088/1757-899X/671/1/012137

9) N. Fadaei, et al. "Experimental investigation of solar chimney with phase change material (PCM)" Renewable energy, $123 \quad 26-35 \quad$ (2018). https://doi.org/10.1016/j.renene.2018.01.122

10) H. Kreetz "Theoretical studies and design of a reservoir for temporary use by solar chimney power plant." Diploma thesis, Technical University Berlin. (1997).

11) J.R. Schlaich, et al. "Design of commercial solar updraft tower systems-utilization of solar induced convective flows for power generation" J. Sol. Energy Eng., 127(1) 117-124 (2005). https://doi.org/10.1115/1.1823493

12) A.O. Chikere, et al. "Theoretische Untersuchungen und Auslegung eines temporaren Wasserspeichers fur das Aufwindkraftwerk" Journal of Applied Sciences, 11(11)1345-1359(2009).

13) H.H. Al-Kayiem, et al. "Performance evaluation of hybrid solar chimney for uninterrupted power generation" Energy, 166 490-505 (2019). https://doi.org/10.1016/j.energy.2018.10.115

14) H. Semai, A. Bouhdjar, and S. Larbi "Canopy slope effect on the performance of the solar chimney power plant" International Journal of Green Energy, 14(3) 229-238 (2017). https://doi.org/10.1080/15435075.2016.1253580

15) S. Larbi, et al. "Solar chimney power plant with heat storage system performance analysis in South Region of Algeria" in 3rd International Renewable and Sustainable Energy Conference (IRSEC, IEEE (2015).

16) H. Nasraoui, Z. Driss, and H. Kchaou "Novel collector design for enhancing the performance of solar chimney power plant" Renewable Energy, 145 1658-1671

(2020). https://doi.org/10.1016/j.renene.2019.07.062

17) T.W. von Backström, A. J. Gannon "Compressible flow through solar power plant chimneys" ASME Journal of Solar Energy Engineering, 122 (3) 138-145 (2000).

18) J.P. Pretorius, and D.G. Kröger, "Solar chimney power plant performance" Journal of Solar Energy Engineering, 128 302-311 (2006).

19) M. O. Hamdan "Analysis of a solar chimney power plant in the Arabian Gulf region" Renewable Energy, 36 2593-2598 (2011).

20) A. Koonsrisuk, and T. Chitsomboon, "Accuracy of theoretical models in the prediction of solar chimney performance" Solar Energy, 83 1764-1771 (2009).

21) H. Alrobaei "Hybrid geothermal/solar energy technology for power generation" P.O. Box: 61297; HOON; LIBYA: Higher Institute of Engineering, 2007.

22) K. Young-Deuk, Kyaw Thu, K. C. Ng, "Evaluation and parametric optimization of the thermal performance and cost effectiveness of activeindirect solar hot water plants", Evergreen: joint journal of Novel Carbon Resource Sciences \& Green Asia Strategy, 2 (2), 50-60 (2015).

23) Z. R.Yabuz "Constructive improvement studies and investigation of methods to increase solar chimney performance" [MSc thesis]. ISPARTA: SDÜ Fen Bilimleri Enstitüsü; 2009.

24) T. Ming, T. Gong, R.K. de-Richter, Y. Wu, and W.Liu "A moist air condensing device for sustainable energy production and water generation" Energy Convers Manag, 138 (6)38-50(2017).

25) H.H. Al-Kayiem, K.Y. Yin, and C.Y. Sing "Numerical simulation of solar chimney integrated with exhaust of thermal power plant" In: WIT transactions on engineering sciences, 7 WIT Press (2012).

26) F. V. Risto, S. V. Filip, and S. Valentino "A CFD study of a solar chimney power plant operation" Proceedings, (Editor A. Olabi), 6th Int. Conf. on Sustainable Energy and Environmental Protection SEEP 2013, Maribor, Slovenia, 631-636 (2013).

27) C. Marija, and F. V. Risto "Efficiency of solar-tracking liquid flat-plate solar energy collector" Int. Journal of Thermal Science, (2015).

28) W. A. Fiveland "Three-dimensional radiative heattransfer solutions by the discrete-ordinates method" Journal of Thermophysics, 2(4)309-316(1988).

29) H.H. Al-Kayiem, K.V. Sreejaya, S.I. Gilani "Mathematical analysis of the influence of the chimney height and collector area on the performance of a roof top solar chimney" Energy Build , 68(3)05-11(2014).

30) F. Cao, H. Li, L. Zhao, T. Bao, and L.Guo "Design and simulation of the solar chimney power plants with TRNSYS" Solar Energy 98 23-33(2013).

31) K. Marzia, F. H. Muhammad, M. Takahiko, B. S. Bidyut, K. Shigeru, "Key Factors of Solar Energy Progress in Bangladesh until 2017", Evergreen: Joint Journal of Novel Carbon Resource Sciences \& Green Asia Strategy, 5(2) 78-85(2018).

\section{Nomenclature}

$\mathrm{Cp}$ - Specific heat of air (J/kg. K)

$V_{\text {coll }}$ - Air velocity at the collector $(\mathrm{m} / \mathrm{s})$

$V_{\text {coll-exit }}$ - Air velocity at the collector exit $(\mathrm{m} / \mathrm{s})$

$V_{\text {air-ch }}$ - Air velocity at the chimney $(\mathrm{m} / \mathrm{s})$

$V$ air-ch - Air flow rate at the chimney $\left(\mathrm{m}^{3} / \mathrm{s}\right)$

$p_{\text {air-ch }}$ - Pressure at the chimney $\left(\mathrm{N} / \mathrm{m}^{2}\right)$

$r_{\text {coll }}$ - Radius of the collector $(\mathrm{m})$

$r_{c h}$ - Radius of the chimney (m)

$H_{g-c}$ - Height from collector ground to the canopy (m) 
$H_{c h}$ - Height of the chimney (m)

$\rho_{\text {air }}-$ Air density $\left(\mathrm{kg} / \mathrm{m}^{3}\right)$

$\rho_{\text {air -coll }}$ - Air density at the collector $\left(\mathrm{kg} / \mathrm{m}^{3}\right)$

$\rho_{\text {air -ch }}$ - Air density at the chimney $\left(\mathrm{kg} / \mathrm{m}^{3}\right)$

$\tau_{\text {air-ch }}$ - kinetic energy source term $\left(\mathrm{N} / \mathrm{m}^{2}\right)$ 